\title{
Contents, Vol. 26, 1965
}

\section{Vol. 26}

Aron, A. S.; Rose, M. J. Jr. and Janicki, B. W. (Washington):

Comparative Serologic Reactivity of I131 and I125 Labelled Human Serum

Albumin Preparations 255

Aronson, S. B.; Rapp, W.; Kushner, I. and Burtin, P. (Villejuif):

Evaluation of Normal Gastric Mucosal Antigens and Enzymes in Cancerous Human Gastric

Mucosa by Agar- and Immuno-Electrophoresis . 327

Barrett, J. T. (Gothenburg):

An Antibody to Porcine Carboxypeptidase B 158

Beall, G. N.: Histamine in Human Urine

Blazkovec, A. A. and Wolfe, H. R.:

Factors Affecting the Primary and Secondary Responses to Bovine Serum

Albumin Chickens 82

Brown, R. A. and West, G. B. (London):

The Antihistaminic Activity of Lysozyme 204

Burtin, P.: vide Aronson, S. B.

Butculescu, I.: vide Cîrstea, M.

Chorzelski, T.: vide Inderbitzin, Th.

Cîrstea, M.; Suhaciu, G. and Butculescu, I. (Bucharest):

Bradykinin and Anaphylactic Shock in Dogs356

Clairmont, J.-P.: vide Lawler, R.

Clements, A. N.: vide Wilson, Anna B.

Colinet-Lagneaux, D.: vide Marcelle, R.

Coombs, R. R. A.; Matthew, R. H., the late; Skinner, Marion E. and Parish, W. E.

An Antibody-Like Factor in Guinea-Pig Serum Reacting in Passive

Haemagglutination Tests with Guinea-Pig Milk 96

Floersheim, G. L. (Basel):

Effect of Pertussis Vaccine on the Tuberculin Reaction

Gözsy, B.: vide Lawler, $\mathrm{R}$.

Hanna, M. G. Jr. (Ook Ridge):

Germinal Center Changes and Plasma Cell Reaction During the Primary

Immune Response 230

Hargis, Betty J.: vide Malkiel, S.

Heilman, Dorothy H.:

The Selective Toxicity of Endotoxin for Phagocytic Cells of the Reticuloendothelial System 63

Hirt, M. (Wood): Validation of a Multiple Regression Equation to Predict the Energy

Expenditure of Patients with Bronchial Asthma 153 
Physical Conditioning in Asthma II. Changes in VEbtps $>V^{\circ} 2$, and

External Work 191

Holm, S. E.: A Modified Gel Chamber Technique for Immunodiffusion Analysis 34

Hönig, Shoshana: vide Schwartz, Jeanna

Inderbitzin, Th. ; Maag, F. and Chorzelski, T. (Boston):

Studies on the Permeability Increasing Factor (P.I.F.)

181

Isvaneski, M.: vide Jankovíc, B. D. Janicki, B. W.: vide Aron, A. S.

Jankovíc, B. D.; Isvaneski, M.; Popeskovic Ljiljana and Mitrovic Kosana:

Experimental Allergic Thyroiditis (and Parathyroiditis) in Neonatally

Thymectomized and Bursectomized Chickens. Participation of the Thymus

in the Development of Disease

18

Johanovský, J.: vide Kolín, A.

Johnson, C. W.: Use of Different In Vivo Procedures to Determine Antibody Response

of Guinea-Pigs to Injections of Protein Antigens

Kátó, L.: vide Law\%oer, R. Klopstock, A.: vide Schwartz, Jeanna

Kolín, A.; Johanovský, J. and Pekárek, J. (Prague):

Histological Manifestations of Cellular (Delayed) Hypersensitivity ... 167

Kushner, I.: vide Aronson, S. B.

Lang, N. (Marburg):

Antikörper gegen Transaminasen 345

Larson, D. A. (Austin):

Cytoplasmic Fine Structure in Airborne Pollen

127

Lawler, R.; Clairmont, J.-P.; Kátó, L. and Gözsy, B. (Montreal):

Investigations into the Mechanism of Pertussis Vaccine Induced Hyper

sensitivity $\quad 373$

Lecomte, J.: vide Marcelle, $\mathrm{R}$.

Leskowitz, S.: vide Salvaggio, J. E.

Maag, F.: vide Inderbitzin, Th.

Malkiel, S. and Hargis, Betty J. (Boston):

Anaphylaxis in Mice Inoculated with an Adrenotrophic Pituitary Tumor 319

Marcelle, R. et Petit, J. M. (Liège):

Effets des aerosols d'acétylcholine, d'atropine et de dipenzheptropine sur

les resistances dynamiques pulmonaires de sujets sains 105

Marcelle, R.; Petit, J. M.; Melon, J. et Lecomte, J. (Liège):

Sensibilité bronchique à Phistamine de l'asthmatique, comparée à celle

du sujet normal 215

Marcelle, R.; Melon, J.; Petit, J. M.; Troqjuet, J. et Colinet-Lagneaux, D. (Liège):

Resistance au debit aérien et valeurs spirographiques classiques chez

l'asthmatique 280

Matthew, R. H., the late: vide Coombs, R. R. A.

Melon, J.: vide Marcelle, $\mathrm{R}$.

Mitrovic Kosana: vide Jankovíc, B. D.

Parish, W. E.: vide Coombs, R. R. A.

Pekárek, J.: vide Kolín, A.

Petit, J. M.: vide Marcelle, R.

Popeskovic Ljiljana: vide Jankovíc, B. D. 
Rapp, W.: vide Aronson, S. B.

Rose, J. M., Jr.: vide Aron, A. S.

Salvaggio, J. E. and Leskowitz, S. (New Orleans):

A Comparison of the Immunologic Responses of Normal and Atopic

Individuals to Parenterally Injected, Alum Precipitated Protein Antigen 264 Sanyal, R. K. and

West, G. B. (New Delhi):

The Role of Histamine and 5-Hydroxytryptamine in Injury 362

Schwartz Je ann a; Klopstock, A. and Vardinon, N. (Tel Aviv):

The Role of the Complement in the Basophile Cells Test 142

Schwartz, Jeanna; Klopstock, A.; Zikert-Duvdevani, Poriya and Hönig Shoshana (Tel

Aviv): Detection of Hypersensitivity by Indirect Rat Mast Cells Degranulation 333

Skinner, Marion E.: vide Coombs R. R. A.

Suhaciu, G.: vide Cîrstea, M.

Troquet, J.: vide Marcelle, R.

Vardinon, N.: vide Schwartz Jeanna

West, G. B.: vide Brown, R. A.

West, G. B.: vide Sanyal, R. K.

Wilson, Anna B. and Clements, A. N. (London):

The Nature of the Skin Reaction to Mosquito Bites in Laboratory Animals 294 Wolfe, H. R.: vide Blazkovec, A. A. Zikert-Dudevani, Poriya: vide Schwartz, Jeanna

Book Reviews - Buchbesprechungen - Livres Nouveaux $\quad$ 62, 125, 153, 190, 315

Proceedings - Gesellschaftsberichte - Sociétés :

British Allergy Society; Meeting of the 29th February 1964 ..... $\quad 57$

British Allergy Society; Meeting of the 13th June 1964

Société Française d'Allergie: Seance du 14 mars 1964

Société Française d'Allergie: Seance du 9 juin 1964

Société Française d’Allergie: Seance du 24 octobre 1964

New Items - Nachrichten - Nouvelles 252, 315

All rights, including that of translation into foreign languages, reserved.

Photomechanic reproduction (photocopy, microcopy) of this book or part of it without specia permission of the publishers is prohibited.

Copyright 1965 by S. Karger AG, Basel

Printed in Switzerland by Buchdruckerei Aargauer Tagblatt AG, Aarau.

Cliches: Steiner \& Cie. AG, Basel. 